\title{
The Polyphenols $\alpha$-Mangostin and Nordihydroguaiaretic Acid Induce Oxidative Stress, Cell Cycle Arrest, and Apoptosis in a Cellular Model of Medulloblastoma
}

\author{
Alberto Rojas-Ochoa ${ }^{1, *}$, Emilio J. Córdova ${ }^{2}$ (), Adela Carrillo-García ${ }^{3}$, Marcela Lizano ${ }^{3,4}$, \\ José Pedraza-Chaverri ${ }^{5}$ (D) Nelly Patiño ${ }^{6}$, Alfredo Cruz-Gregorio ${ }^{5}$ and Norma Osnaya ${ }^{7}$
}

check for updates

Citation: Rojas-Ochoa, A.; Córdova, E.J.; Carrillo-García, A.; Lizano, M.; Pedraza-Chaverri, J.; Patiño, N.; Cruz-Gregorio, A.; Osnaya, N. The Polyphenols $\alpha$-Mangostin and Nordihydroguaiaretic Acid Induce Oxidative Stress, Cell Cycle Arrest, and Apoptosis in a Cellular Model of Medulloblastoma. Molecules 2021, 26 , 7230. https://doi.org/10.3390/ molecules 26237230

Academic Editors: Brullo Chiara and Bruno Tasso

Received: 29 October 2021

Accepted: 24 November 2021

Published: 29 November 2021

Publisher's Note: MDPI stays neutral with regard to jurisdictional claims in published maps and institutional affiliations.

Copyright: (C) 2021 by the authors. Licensee MDPI, Basel, Switzerland. This article is an open access article distributed under the terms and conditions of the Creative Commons Attribution (CC BY) license (https:// creativecommons.org/licenses/by/ $4.0 /)$.
1 Laboratorio de Oncología Experimental, Subdirección de Medicina Experimental, Instituto Nacional de Pediatría, Ciudad de México 04530, Mexico

2 Consorcio de Oncogenómica, Instituto Nacional de Medicina Genómica, Ciudad de México 14610, Mexico; ecordova@inmegen.gob.mx

3 Subdirección de Investigación Básica, Instituto Nacional de Cancerología, Ciudad de México 14080, Mexico; acarrillog@incan.edu.mx (A.C.-G.); lizano@unam.mx (M.L.)

4 Departamento de Medicina Genómica y Toxicología Ambiental, Instituto de Investigaciones Biomédicas, Universidad Nacional Autónoma de México, Ciudad de México 04510, Mexico

5 Departamento de Biología, Facultad de Química, Universidad Nacional Autónoma de México, Ciudad de México 04510, Mexico; pedraza@unam.mx (J.P.-C.); cruzgalfredo@comunidad.unam.mx (A.C.-G.)

6 Unidad de Citometría de Flujo (UCiF), Instituto Nacional de Medicina Genómica, Ciudad de México 14610, Mexico; lnpatino@inmegen.gob.mx

7 Laboratorio de Neurociencias, Subdirección de Medicina Experimental, Instituto Nacional de Pediatría, Ciudad de México 04530, Mexico; nosnayab@pediatria.gob.mx

* Correspondence: arochoa67@hotmail.com; Tel.: +52-551-084-0900 (ext. 2053/1474); Fax: +52-555-606-3489

\begin{abstract}
Medulloblastoma is a common malignant brain tumor in the pediatric age. The current therapeutics present serious collateral effects. Polyphenols $\alpha$-mangostin and nordihydroguaiaretic acid (NDGA) exert potent antitumoral activity in different cancer models, although their antitumoral effects have not been described in medulloblastoma cells yet. This study aimed to examine the proapoptotic effects of these polyphenols on human medulloblastoma cells. Medulloblastoma cell line Daoy was incubated with increasing concentrations of $\alpha$-mangostin or NDGA for $24 \mathrm{~h}$. The cell viability was analyzed using crystal violet and trypan blue dyes. Determination of the glutathione (GSH)/glutathione disulfide (GSSG) ratio and levels of carbonylated proteins was performed to evaluate the oxidative stress. Cell cycle progression and induction of cell death by fluorochromecouple and TUNEL assays were evaluated using flow cytometry assays. Individual treatments with $\alpha$-mangostin or NDGA decreased the viability of Daoy cells in a dose-dependent manner, inducing G2/M and S-G2/M cell cycle arrest, respectively. Both polyphenols induced cell death and increased oxidative stress. Very interestingly, $\alpha$-mangostin showed more potent effects than NDGA. Our results indicate that $\alpha$-mangostin and NDGA exert important cytostatic and cytotoxic effects in the Daoy cell line. These data highlight the potential usefulness of these compounds as an alternative strategy in medulloblastoma treatment.
\end{abstract}

Keywords: medulloblastoma; $\alpha$-mangostin; NDGA; cancer; cell cycle; apoptosis

\section{Introduction}

Medulloblastoma, a malignant tumor that develops in the cerebellum, is considered the most frequent cerebral cancer in the pediatric age, accounting for approximately $20 \%$ of all primary neoplasia of the central nervous system [1]. This tumor is diagnosed in children younger than 15 years old, usually between 3 and 9 . The current therapeutic schemes used in medulloblastoma patients are based on neurosurgery, craniospinal radiotherapy, and conventional chemotherapy [2]. Although recent therapeutic advances have increased the survival rate of patients, a significant number of collateral adverse effects related to 
these procedures are detrimental to the quality of life of the survivors [2,3]. These side effects include important affectation and deterioration of intellectual function and memory, motor ability deficits, and growth problems [1-3]. Therefore, the discovery of nontoxic therapeutic alternatives against medulloblastoma is still an area of active research.

For centuries, plant-derived compounds have been used in traditional medicine to cure a diversity of human diseases [4,5]. In this regard, mainly two plants have great potential as therapeutic alternatives, the tropical tree native to Southeast Asia known as mangosteen (Garcinia mangostana, Linn) and a creosote bush known as La Gobernadora (Larrea tridentata) or Hediondilla in México and greasewood or chaparral in the United States of America, because both plants have a long history of use in traditional medicine in their original regions. These plants are rich in polyphenols with potent chemopreventive properties and very few or no adverse side effects linked to their consumption in treating various health conditions like inflammation, neurological disorders, aging, arthritis, diabetes, obesity, renal disease, and cancer [6-11]. The abundant polyphenols $\alpha$-mangostin from the fruits produced by mangosteen and nordihydroguaiaretic acid (NDGA) from La Gobernadora have been studied, because they possess excellent beneficial health properties, such as ameliorative effects in cardiovascular and neurological disorders, immune modulation, antiviral effect, tissue engineering, and solid anticancer function [12-15]. The majority of in vivo studies of mangosteen xanthones have focused on murine and rat models and included metabolism and bioavailability analyses, particularly in anticancer activity, which have focused on colon cancer [16]. Remarkably, $\alpha$-mangostin has been shown to inhibit cell proliferation in prostate and breast cancer-derived cell lines $[17,18]$.

Moreover, the proapoptotic properties of $\alpha$-mangostin have been demonstrated in many cancer cellular models. For instance, in prostate cancer cells, $\alpha$-mangostin modulates the endoplasmic reticulum stress (ER) markers, protein kinase RNA-like endoplasmic reticulum kinase (PERK), inositol requiring enzyme (IRE1), and C/EBP homologous protein (CHOP) with the activation of caspase-3, whereas, in breast cancer cells, it activates caspase8 , caspase-9, and caspase-7. In colorectal cancer cells, $\alpha$-mangostin increases the protein levels of the proapoptotic molecules tumor suppressor protein p53, the pro-apoptotic BCL2 gene family member BAX (BAX), poly (ADP-ribose) polymerase (PARP), and the release of Endonuclease-G (Endo-G) from the mitochondria. Moreover, in leukemia-derived cell lines, $\alpha$-mangostin induces nucleosomal DNA fragmentation and the activation of caspase- 9 and caspase-3 [17-21]. Besides, $\alpha$-mangostin exposure reduces the migration and invasion potential of cancer cells derived from pancreatic carcinoma (BxPc-3 and Panc-1) and melanoma (B16-F10) $[22,23]$. On the other hand, it has been shown that $\alpha$-mangostin at $100-1000 \mathrm{mg} / \mathrm{kg}$ did not exhibit any harmful effects on the kidney and liver tissues of murine models [24] and did not affect the cell viability in normal human osteoblasts when treated by $\alpha$-mangostin $(0,10,20,30,40$, and $50 \mu \mathrm{M})$ for 24 and $48 \mathrm{~h} \mathrm{[25] \text {. }}$

NDGA cytotoxic and antitumoral activities have been evaluated, both in cell cultures and in animal models. For instance, NDGA promotes cell death by caspase- 3 cleavage in the breast cancer cell lines SK-BR-3 and BT-474 [26]. In addition, NDGA inhibits growth and induces cell cycle arrest at the G1 phase in cervical cancer-derived cell line SiHa by regulating cell cycle kinase inhibitor p21 and promoting the acetylation of histone $\mathrm{H} 3$ [27]. In the prostate cancer PC 3 cell line, NDGA impairs cell migration and tumor metastasis in nude mice via suppressing the function of single-pass transmembrane protein neuropilin 1 [28]. Regarding the toxic effect of NDGA in no cancer cells, it has been reported that only high concentrations of NDGA $(100 \mu \mathrm{M})$ induce lipid peroxidation, DNA double-stranded breaks, and cell death in rat hepatocytes [29] and do not affect the viability of normal cells and peripheral blood mononuclear cells (PBMC) at 3, 10, 30, and $60 \mu \mathrm{M}$ [30].

There have been several reports of studies with healthy human volunteers where extracts, juices, or teas are used, either from the fruits of mangosteen or of La Gobernadora leaves; in these reports, the bioavailability and metabolism of the compounds containing these plants were studied primarily $[9,16,31-33]$. However, although there are as yet no reports of studies related to their neuroprotective and anticancer activities in humans 
with mangosteen or $\alpha$-mangostin, there have been some clinical trials with NDGA or its derivates for various cancer types like prostate, cervical, leukemia, and glioma, though no conclusive results have been reported [34]. For instance, in a terminated phase II clinical trial, subjects with nonmetastatic hormone-sensitive prostate cancer (HSPC) were treated with oral NDGA; the patients presented no significant prostate-specific antigen (PSA) declines after three cycles of treatment, so the researchers did not recommend NDGA as a monotherapy in this population [35]. In another completed phase I clinical trial, the intravenously NDGA analog called Terameprocol defined the toxicity profile in men with recurrent high-grade gliomas; this phase I study defined the dose for future studies with terameprocol and suggested that safely combining this compound with chemotherapy drugs and with radiation to study its synergistic effects in newly diagnosed high-grade gliomas could be accomplished [36].

Although $\alpha$-mangostin and NDGA have been proposed as potential alternatives in treating different types of cancer, there have been no reports of the anticancerous effects of these polyphenols during human in vivo models or even in vitro models of medulloblastoma. Thus, the present study aimed to evaluate the cytostatic and cytotoxic effects of $\alpha$-mangostin and NDGA in the childhood medulloblastoma-derived cell line Daoy, which belongs to Sonic Hedgehog $(\mathrm{SHH})$, which is the second-most common subgroup in children under three years old and adolescents in approximately 33\% of all the subgroups. Our results showed that both $\alpha$-mangostin and NDGA exerted cytostatic and cytotoxic effects in the Daoy cell line, probably by the oxidative stress produced for these polyphenols, with $\alpha$-mangostin having more substantial effects than NDGA. These polyphenols provoked arrest in different stages of the cell cycle, suggesting the involvement of independent cellular mechanisms, and we also observed that, importantly, these compounds induced apoptosis in medulloblastoma cell line Daoy. Our data highlighted the potential usefulness of these compounds as an alternative strategy in medulloblastoma treatment.

\section{Results}

\subsection{Effects of $\alpha$-Mangostin and NDGA on Cell Viability in Daoy Cells}

We first determined the effect of increasing concentrations of $\alpha$-mangostin and NDGA on the viability of medulloblastoma cells. We found a dose-dependent reduction in the number of attached cells in $\alpha$-mangostin and NDGA-treated cell cultures (Figure 1A,B). However, this decrease was observed with lower concentrations of $\alpha$-mangostin $(15 \mu \mathrm{M}=88.93 \%$, $20 \mu \mathrm{M}=55.92 \%$, and $40 \mu \mathrm{M}=11.88 \%)$ than NDGA $(50 \mu \mathrm{M}=83.09 \%, 75 \mu \mathrm{M}=54.19 \%$, and $100 \mu \mathrm{M}=23.19 \%$ ).

Using the trypan blue exclusion assay, we also observed a dose-dependent decrease in cellular viability after $\alpha$-mangostin $(15 \mu \mathrm{M}=71.71 \%, 20 \mu \mathrm{M}=48.15 \%$, and $40 \mu \mathrm{M}=7.32 \%)$ or NDGA treatments ( $50 \mu \mathrm{M}=85.48,75 \mu \mathrm{M}=42.78 \%$, and $100 \mu \mathrm{M}=35.31 \%$ ) (Figure $1 \mathrm{C}, \mathrm{D})$ ). The reduction in cell viability was observed again, with lower concentrations of $\alpha$-mangostin compared to NDGA. These data indicated a more potent effect of $\alpha$-mangostin than NDGA on Daoy cell growth.

\subsection{The $\alpha$-Mangostin and NDGA Promote Oxidative Stress in Daoy Cells}

After observing that $\alpha$-mangostin and NDGA affected the cell number and viability in the cell cultures, and knowing that, in some conditions, these compounds can induce oxidative stress (OS), which is one of the mechanisms that induce cell death, we measured the intracellular levels of glutathione and carbonyl proteins in Daoy cells treated with $\alpha$-mangostin and NDGA as markers of OS. We observed a nonsignificant decrease in the glutathione levels (Figure 2A), as well as a 4- and 4.5-fold increase of GSSG, after the $\alpha$ mangostin and NDGA treatments, respectively (Figure 2B). Consequently, the GSH/GSSG ratio decreased 4.9- and 11-fold for $\alpha$-mangostin and NDGA, respectively (Figure 2C). Additionally, we found that the level of carbonyl protein groups increased with $\alpha$-mangostin and NDGA treatments 2.8- and 2.1-fold, respectively (Figure 2D). Taken together, these results suggest that $\alpha$-mangostin and NDGA treatments induce oxidative damage to pro- 
teins, which might be a possible mechanism of cell death induction by $\alpha$-mangostin and NDGA in the Daoy cell line.
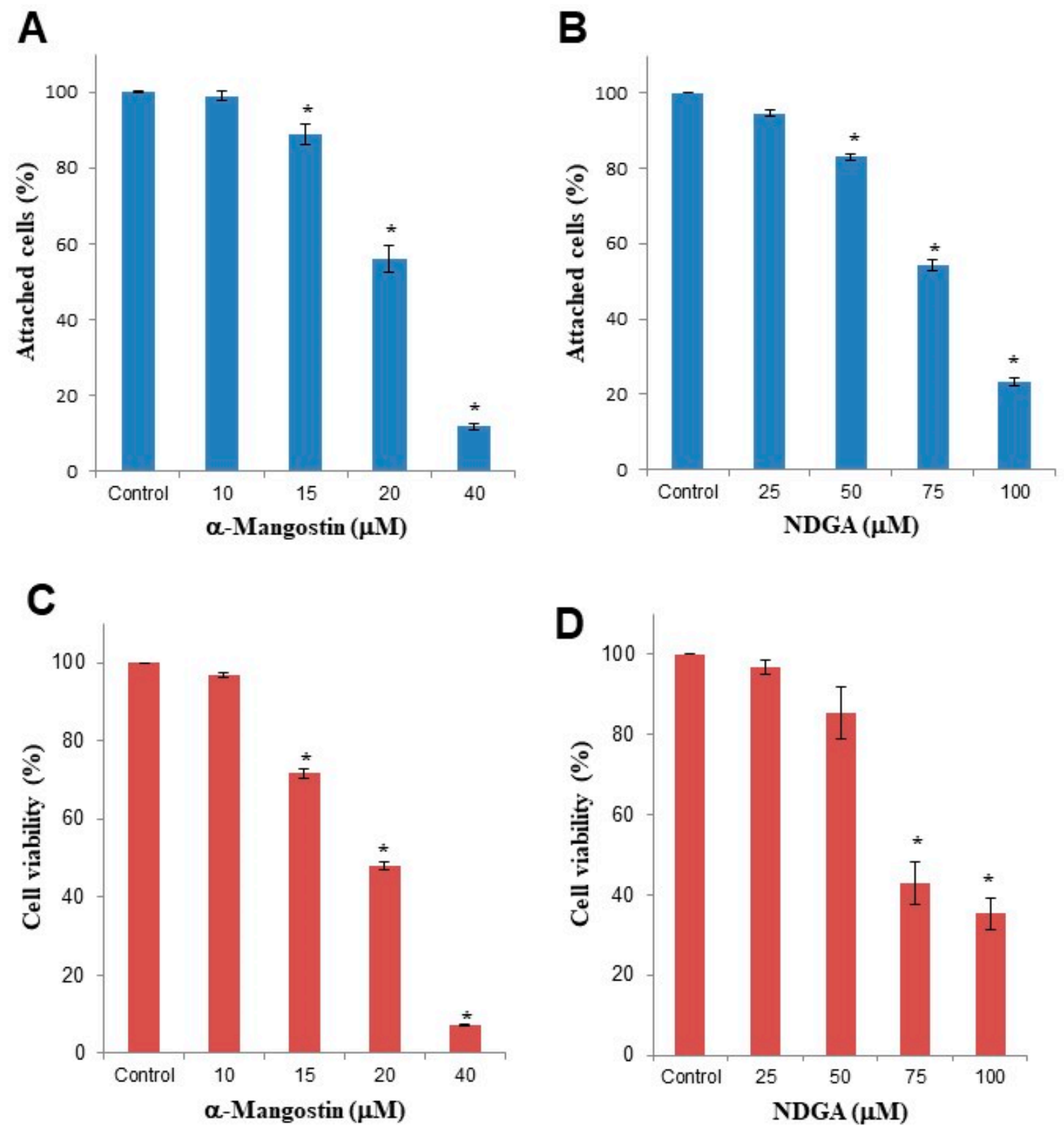

Figure 1. Cellular growth and viability of Daoy cells were decreased by individual treatments with $\alpha$-mangostin or NDGA. The Daoy cell line $\left(1 \times 10^{5}\right.$ cells $\left./ \mathrm{mL}\right)$ was cultured for $24 \mathrm{~h}$ in the presence of increasing concentrations of $\alpha$-mangostin or NDGA. (A,B) The percentage of adherent cells was assessed with a crystal violet assay. (C,D) Cellular viability was determined by the trypan blue exclusion assay. Data represent the mean and standard error (SEM) of at least three independent experiments. One-way analysis of variance and Dunnett's multiple comparison test were used. ${ }^{*} p<0.0001$ vs. control. 
A
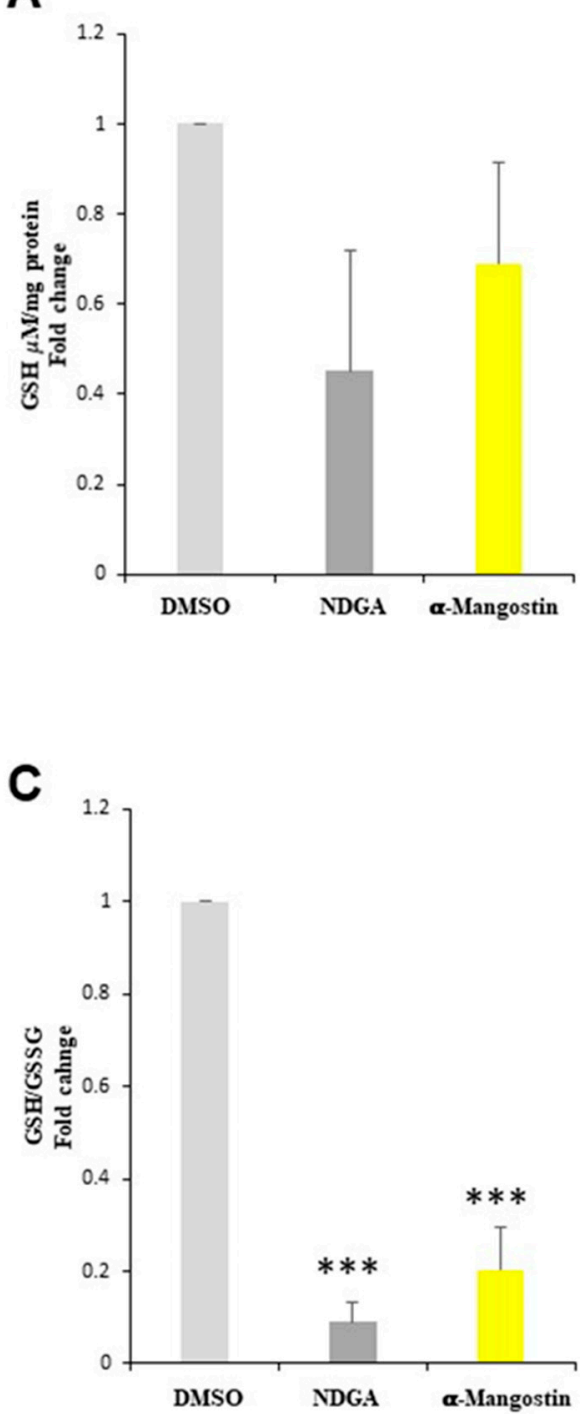

B
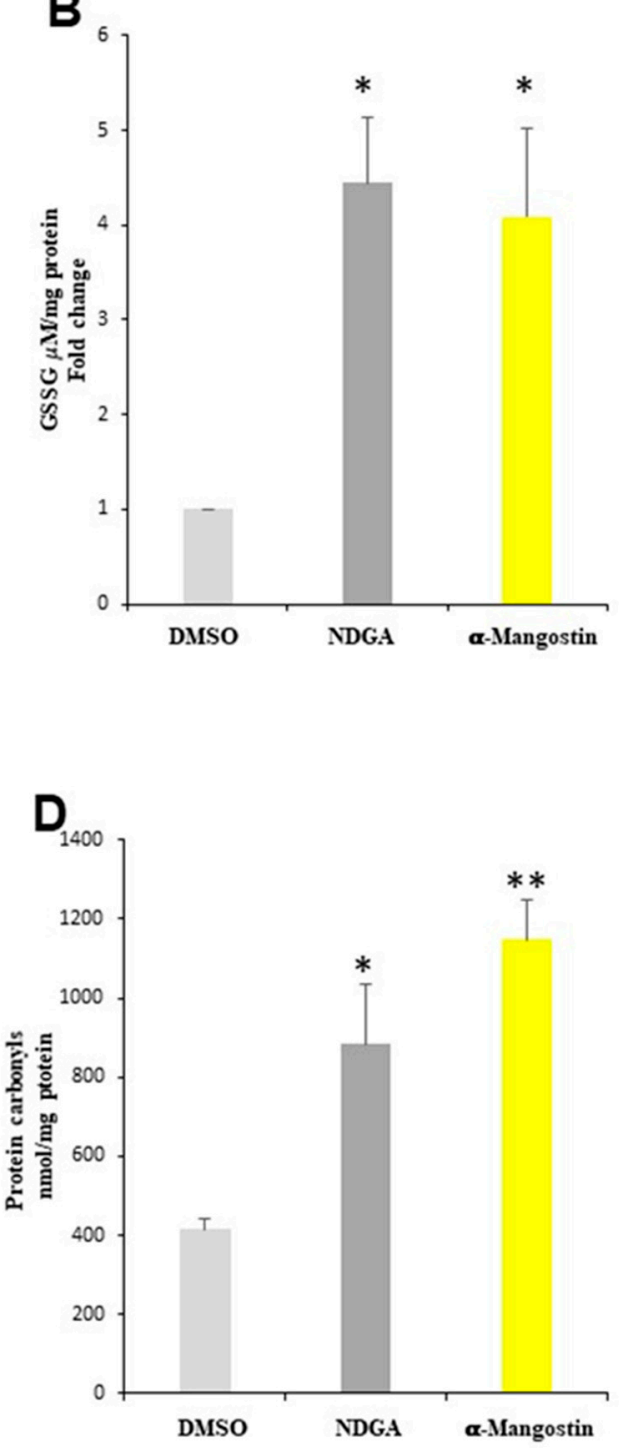

Figure 2. $\alpha$-Mangostin $(20 \mu \mathrm{M})$ and NDGA $(75 \mu \mathrm{M})$ promote oxidative stress in Daoy cells. (A) GSH determination, (B) GSSG determination, (C) GSH/GSSG ratio compared to the control vector, and (D) carbonyl protein determination compared to the control vector. The GS, and GSSG levels are expressed as the mean and SEM. Tukey's test: ${ }^{*} p<0.05$ and ${ }^{* * *} p<0.0005$. The carbonyl protein levels are expressed as the mean and SEM. Tukey's test: ${ }^{*} p<0.05$ and ${ }^{* *} p<0.005$.

\section{3. $\alpha$-Mangostin and NDGA Induced Arrest in Different Stages of the Cell Cycle in Daoy Cells}

Since we found that treatment with $\alpha$-mangostin and NDGA induces OS in Daoy cells in a culture, we decided to analyze whether that OS had any effect on the cell cycle of Daoy cells in the culture; next, we evaluated the effect of each polyphenol on the cell cycle progression with flow cytometry and DNA staining with propidium iodide using dose-response assays. After incubation with $15 \mu \mathrm{M}$ of $\alpha$-mangostin for $24 \mathrm{~h}$, we observed a slight increase in the percentage of Daoy cells at the G2/M phase in comparison with the control cell cultures $(19.70 \%$ vs. $13.51 \%)$, whereas an evident cell cycle arrest in the G2/M phase was observed after incubation with $20 \mu \mathrm{M}$ of $\alpha$-mangostin for $24 \mathrm{~h}(36.83 \%$ vs. $13.51 \%)$. No differences in cell cycle progression were observed in the cultures incubated with $10 \mu \mathrm{M}$ of $\alpha$-mangostin in comparison with the control cultures $(13.51 \%$ vs. $10.45 \%)$ (Figure 3A,C). It is worth noting that a subG0/G1 peak, representing the apoptotic cell population, was observed in the treatments with 15 and $20 \mu \mathrm{M}$ of $\alpha$-mangostin $(22.81 \%$ and $25.31 \%$, respectively), but it was not observed in the treatment with $10 \mu \mathrm{M}$ of $\alpha$-mangostin (Figure 3A). 
A

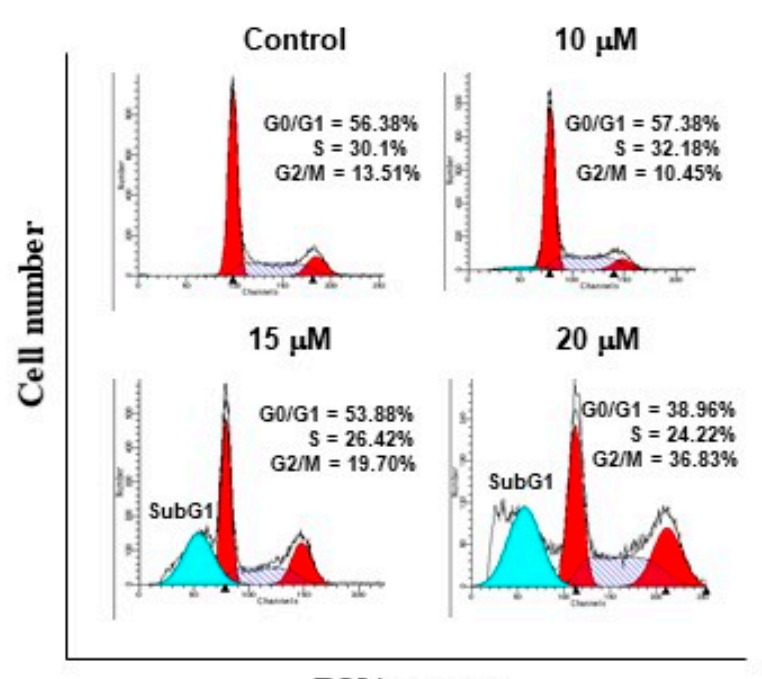

DNA content

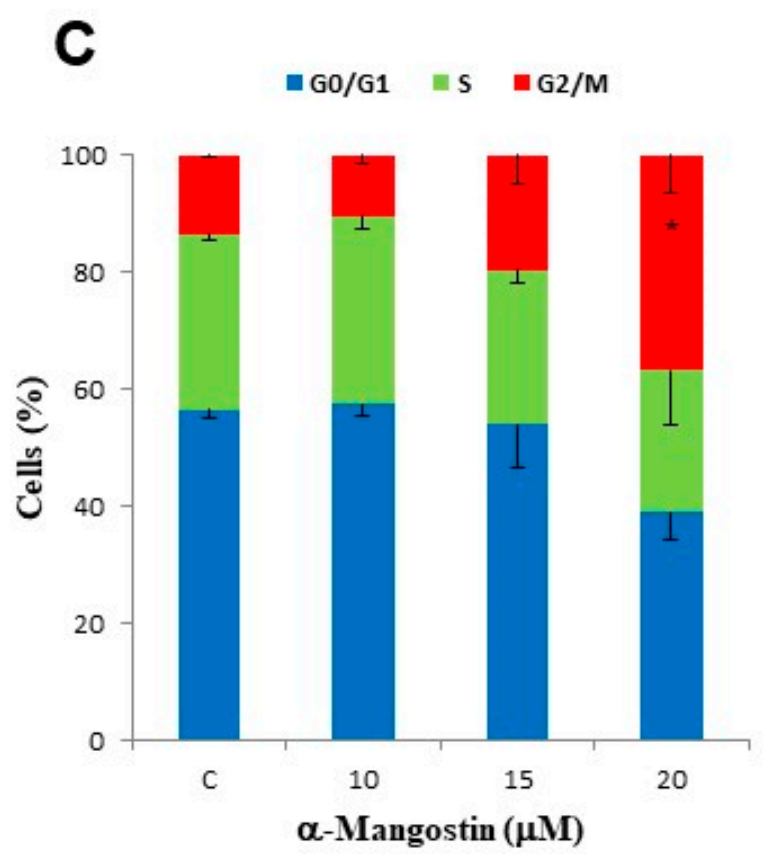

B

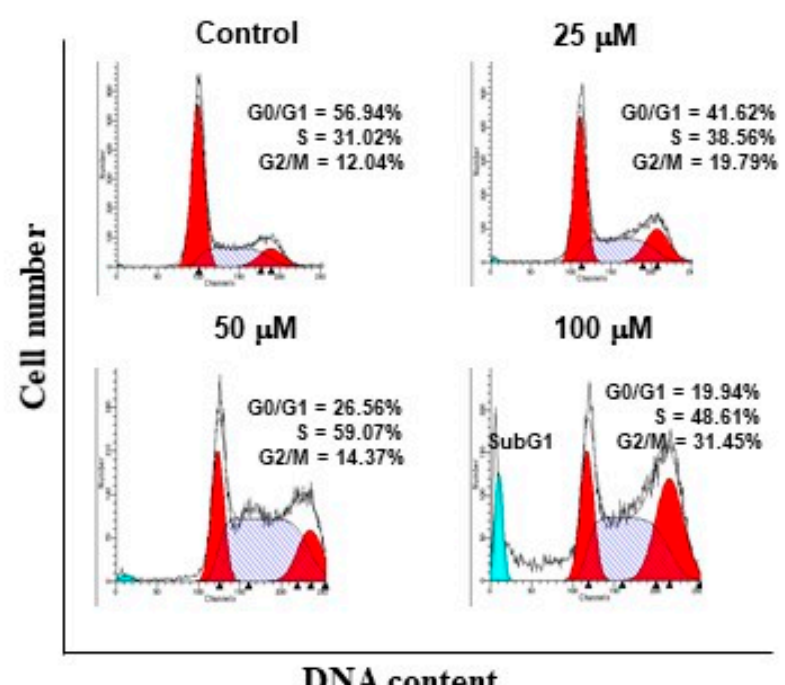

DNA content

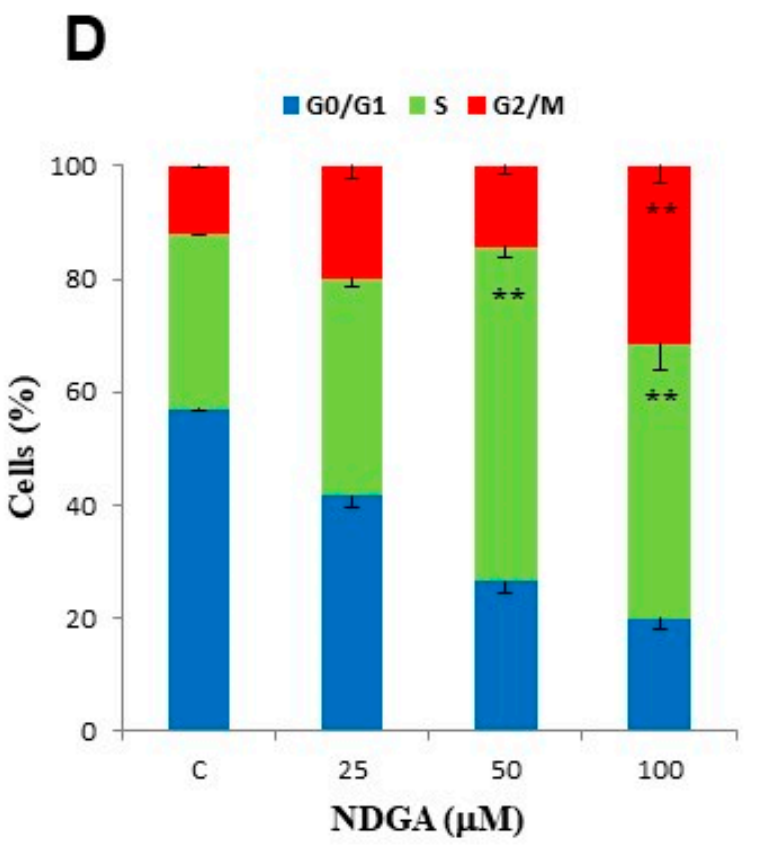

Figure 3. Treatment with $\alpha$-mangostin and NDGA induced cell cycle arrest in Daoy cells. Daoy cells $\left(1 \times 10^{6}\right.$ cells $)$ were treated with increasing doses of $\alpha$-mangostin or NDGA, stained with propidium iodide, and analyzed by flow cytometry. (A,B) Representative histograms and the mean of at least three independent assays are shown. (C,D) Graphical representation of the cell cycle data in panels A and B. Data represent the mean and SEM of at least three independent experiments. Two-way ANOVA and Bonferroni posttests: ${ }^{*} p<0.05$ and ${ }^{* *} p<0.001$.

In the case of NDGA, we found an initial increase in the percentage of Daoy cells at the $S$ phase after treatment with $50 \mu \mathrm{M}$ in comparison with the control cell cultures $(59.07 \%$ vs. $31.02 \%$ ), followed by a slight decrease in the percentage of cells in this phase at $100 \mu \mathrm{M}$ (48.61\%), whereas the percentage of cells in the G2/M phase showed a dose-dependent increase at $50 \mu \mathrm{M}(14.37 \%)$ and $100 \mu \mathrm{M}(31.45 \%)$ in comparison with the control cultures $(12.04 \%$ ) (Figure 3B,D). Like $\alpha$-mangostin, we also observed a subG0/G1 peak, but only in the treatment with the highest concentration of NDGA $(100 \mu \mathrm{M})$. The above data suggest that $\alpha$-mangostin and NDGA affect different mechanisms in regulating the cell cycle. 


\section{4. $\alpha$-Mangostin and NDGA Promoted Cell Death in Daoy Cells by Triggering Apoptosis}

As the sub G0/G1 peak detected in the cell cycle assays suggested the presence of apoptosis in Daoy cells treated with these polyphenols, we used a nonpermeable fluorescent probe to detect by flow cytometry the loss of plasma membrane integrity, which is a characteristic of cell death. After $24 \mathrm{~h}$ of treatment with increasing concentrations of $\alpha$ mangostin, we observed a concentration-dependent increase in the percentage of cells with a loss of plasma membrane integrity, starting at concentrations as low as $15 \mu \mathrm{M}(20.80 \%)$ and having the highest percentage of cell death at $40 \mu \mathrm{M}(99.75 \%)(p<0.0001 \mathrm{vs}$. control) (Figure 4A). In contrast, NDGA treatment induced a significant increase in cell death only at the two highest concentrations used in this assay $(75 \mu \mathrm{M}=45.10 \%$ and $100 \mu \mathrm{M}=73.87 \%)$ $(p<0.0001$ vs. control) (Figure 4B).

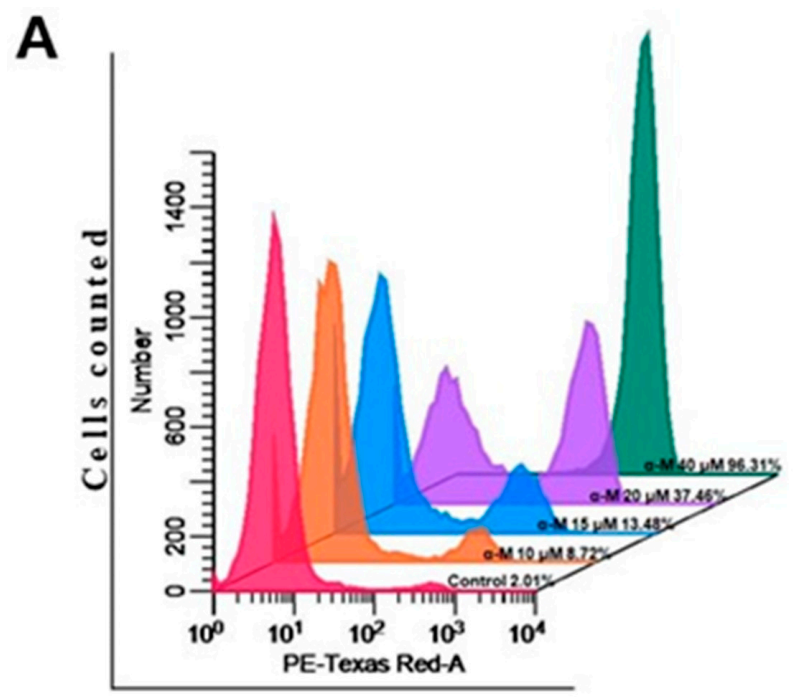

LIVE / DEAD Fluorescent stain

B

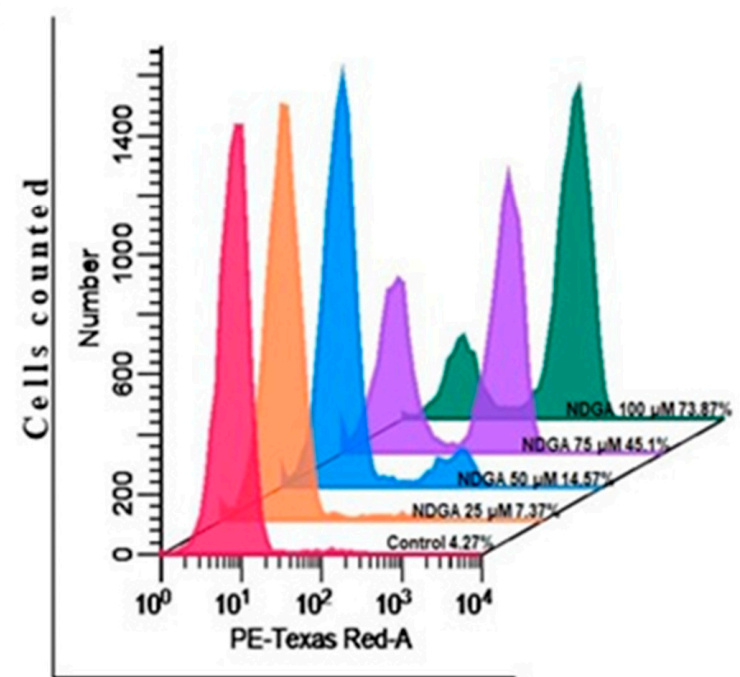

LIVE / DEAD Fluorescent stain

Figure 4. $\alpha$-Mangostin and NDGA induced cytotoxicity in medulloblastoma cells. The cytotoxic effects of $\alpha$-mangostin and NDGA treatment on Daoy cells were determined by LIVE/DEAD assay fluorescent staining. (A,B) Representative histograms of the cytometer determinations are shown. Mean and SEM of at least three independent experiments were analyzed with one-way analysis of variance and Dunnett's multiple comparison test. 
A TUNEL assay was performed to corroborate the presence of apoptosis. This assay detects the fragmentation of chromosomal DNA, one of the hallmarks of late apoptosis. As expected, we observed a significant increase in the percentage of apoptotic cells at increasing concentrations of $\alpha$-mangostin and NDGA (Figure 5A,B). Following the assays related to membrane integrity, apoptotic cells began to emerge at $\alpha$-mangostin concentrations of $15 \mu \mathrm{M}(8.31 \%)$, showing concentration-dependent increases at $20 \mu \mathrm{M}(47.81 \%)$ and $40 \mu \mathrm{M}(92.65 \%)(p<0.0001$ vs. control). In contrast, the concentration of $10 \mu \mathrm{M}$ showed no significant increase in the percentage of cell death (Figure 5A). In the case of NDGA, the concentrations of $75 \mu \mathrm{M}$ and $100 \mu \mathrm{M}$ induced a marked dose-dependent increase in the percentage of apoptotic cells ( $14.85 \%$ and $20.63 \%$, respectively) compared to the control cultures ( $p<0.0001$ vs. control) (Figure 5B). It is worth noting that the percentage of apoptotic cells induced by $20 \mu \mathrm{M}$ of $\alpha$-mangostin was higher than that induced by $100 \mu \mathrm{M}$ of NDGA ( $47.81 \%$ vs. $20.63 \%)$. Overall, our data indicated that $\alpha$-mangostin has a more potent proapoptotic effect than NDGA in Daoy cells.

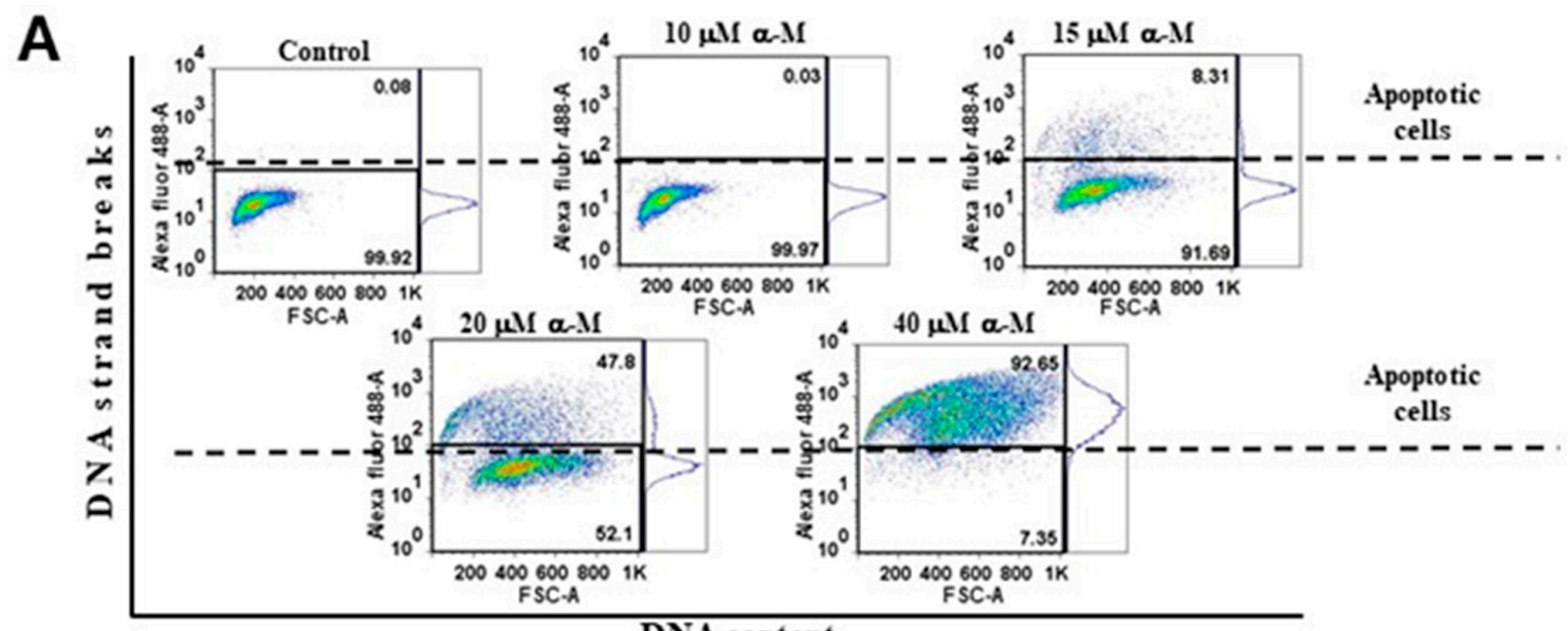

DNA content

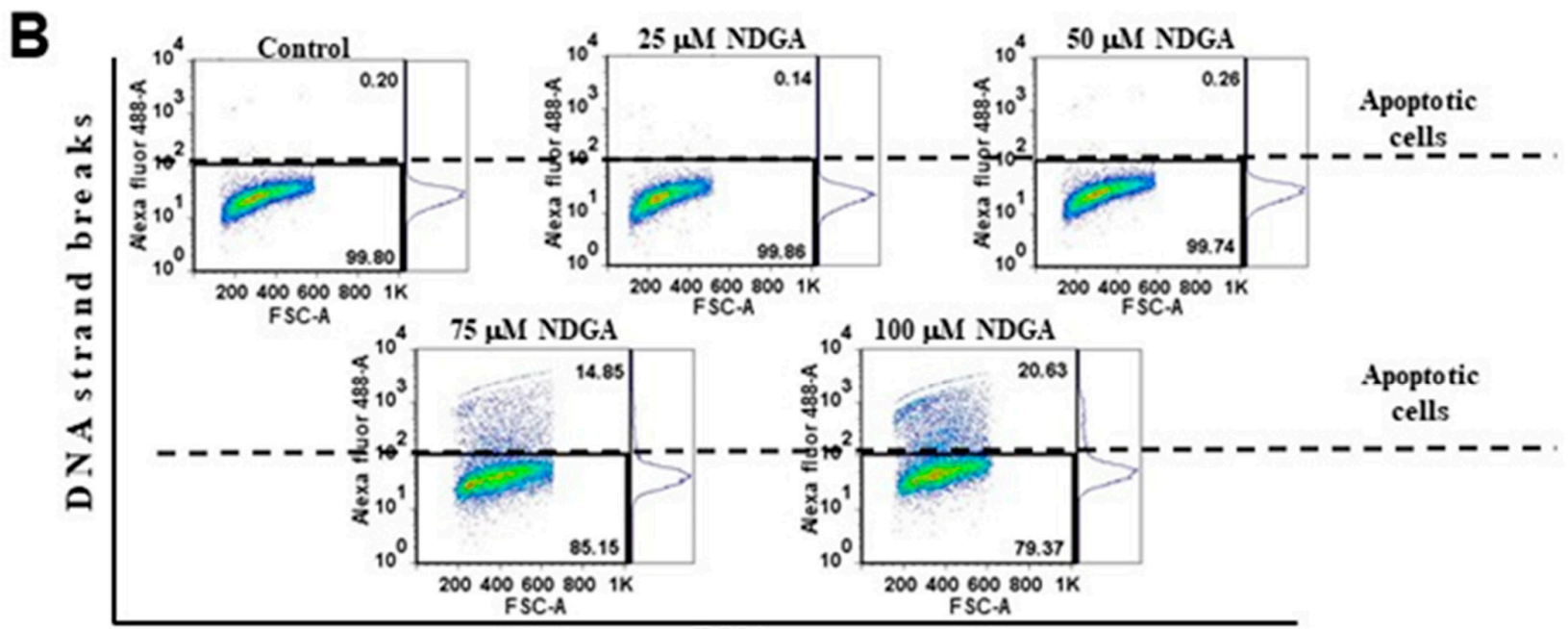

DNA content

Figure 5. TUNEL assay of the dose-response curves of $\alpha$-mangostin and NDGA on Daoy cells. (A,B) Representative histograms (dot plots) are shown. The Q1 region in the dot plots represents TUNEL-positive staining cells with the APO-BrdUTM TUNEL Assay kit. Mean and SEM of at least three independent experiments were analyzed with one-way analysis of variance and Dunnett's multiple comparison test. 


\section{Discussion}

Medulloblastoma is the most common cerebral malignant tumor in the pediatric age, and the current therapeutic strategies present severe side effects. Recently, several studies with dietary polyphenols such as $\alpha$-mangostin and NDGA have discovered their potential functions in preventing and treating many types of cancer [12-15]. However, no studies about the antitumoral effects of these polyphenols in childhood medulloblastoma cells have been performed yet. Here, we report, for the first time, the cytostatic and pro-apoptotic effects of $\alpha$-mangostin and NDGA in Daoy cells, a medulloblastoma-derived cell line.

We found an inhibitory effect of $\alpha$-mangostin on cell growth in the Daoy cell line with a $50 \%$ reduction after $24 \mathrm{~h}$ of exposure to $20 \mu \mathrm{M}$ of the phytochemical and complete suppression of cell growth after incubation with $40 \mu \mathrm{M}$. According to our findings, previous studies have reported the ability of $\alpha$-mangostin to decrease cell growth near to $50 \%$ in human cancer cells, which ranged from $3.57 \mu \mathrm{M}$ in breast cancer to $20 \mu \mathrm{M}$ in colon carcinoma [37-40]. In the case of NDGA, the inhibitory effect on cell growth was at higher concentrations, ranging from 50 to $200 \mu \mathrm{M}$, where $50 \%$ inhibitory cell growth was found near $75 \mu \mathrm{M}$. The inhibitory effect of NDGA in cell growth has been reported in cervical and breast cancer cells in a concentration-dependent manner from 20 to $100 \mu \mathrm{M}$ [26,27].

We also found that $\alpha$-mangostin and NDGA induce a significant decrease in the GSH/GSSG ratio associated with the augmentation of carbonyl proteins in Daoy cells. This condition involves the increase of reactive oxygen species (ROS). Our results matched the effect of $\alpha$-mangostin in cancer cell lines, as shown by Lee et al. [41]. This group showed that $\alpha$-mangostin increased the ROS in cancer cell lines, resulting in loss of the mitochondrial membrane potential (MMP), in the increase of proapoptotic protein Bax, and the decrease of antiapoptotic proteins such as Bcl-2, which induce cytochrome $\mathrm{C}$ release and activation of caspase-9/caspase-3, promoting apoptosis [41].

In addition, after exposing the Daoy cell line to $20 \mu \mathrm{M}$ of $\alpha$-mangostin for $24 \mathrm{~h}$, we observed G2/M cell cycle arrest. In contrast, most of the studies reporting the cytostatic effects of $\alpha$-mangostin in cellular cancer models showed an arrest at the G1 phase, using concentrations ranging from $8 \mu \mathrm{M}$ to $20 \mu \mathrm{M}$ in different incubation periods. For instance, in pancreatic cancer cells BxPc-3 and Panc- $1, \alpha$-mangostin treatment induced a decrease of cyclin-D1 followed by cell cycle arrest at the G1 phase [22]. Similarly, in B16-F10 melanoma cells, $15 \mu \mathrm{M}$ of $\alpha$-mangostin induced G1 arrest after $24 \mathrm{~h}$ of treatment [23]. Moreover, in cell lines derived from oral squamous cell carcinoma (HSC-2, HSC-3, and HSC-4) and colon carcinoma (DLD-1), $\alpha$-mangostin induced G1 arrest by downregulating CDK4, CDK2, cyclin D3, and cyclin E, as well as through the upregulation of the p27 $7^{\mathrm{kip} 1}$ and $\mathrm{p} 21^{\text {waf1/cip1 }}$ CDK inhibitors [40,42]. Besides, in human breast cancer cell line MDA-MB231, G1 arrest induced by $\alpha$-mangostin was associated with the augmentation of $\mathrm{p} 21^{\text {waf1 } 1 / \mathrm{cip} 1}$, a decreased expression of proliferating cell nuclear antigen (PCNA) and cyclin D1 [38]. On the other hand, and similar to our results, Mizushina et al. [39] reported a cell cycle arrest in the G2/M phase in human colon carcinoma HCT116 cells exposed to $18.5 \mu \mathrm{M}$ of $\alpha$-mangostin in $24 \mathrm{~h}$. This arrest was associated with inhibiting cellular DNA topoisomerase I and II activity, suggesting that $\alpha$-mangostin might be a new type of suppressor of topoisomerase functions. Our data indicated that $\alpha$-mangostin might affect cell cycle progression, depending on the genetic background.

Although NDGA induced a similar arrest in the G2/M phase in Daoy cells, a transient one in the $S$ phase preceded this arrest. These observations indicate that NDGA could alter the cellular processes involved in at least two different phases of the Daoy cell cycle concomitantly. Previous studies reported that NDGA could arrest cells in different cell cycle phases, but transient arrest in the $S$ phase was not reported previously. For instance, Gao et al. [27] reported that NDGA induced cell cycle arrest at the G1 phase in cervical cancer $\mathrm{SiHa}$ cells by upregulating the expression of $\mathrm{p} 21$, a key mediator of G1/S transition. Besides, Zavodovskaya et al. [43] found in human breast cancer cells that the growth inhibitory effects of NDGA were associated with an arrest of the cell cycle in the S phase and apoptosis induction. In SH-SY5Y neuroblastoma cells, Meyer et al. [44] reported that 
NDGA caused cell cycle arrest in sub-G0 in a concentration-dependent manner from 30 to $120 \mu \mathrm{M}$ after $24 \mathrm{~h}$ of treatment. Furthermore, a novel derivative NDGA-based compound, NDGA-P21, could inhibit glioma cell proliferation and arrest the cell cycle in the G1 phase but with poor apoptosis induction [45].

We also documented the proapoptotic properties of $\alpha$-mangostin and NDGA in Daoy cells through the observed accumulation of the sub-G1 cellular population, a loss of the membrane integrity in flow cytometry assays, and the presence of inter-nucleosomal DNA fragments with TUNEL experiments. Consistent with our results, previous reports showed that $\alpha$-mangostin and NDGA could induce apoptosis in the diversity of cellular models of cancer. For instance, Li et al. [37] found that $\alpha$-mangostin at $4 \mu \mathrm{M}$ induced apoptosis in human breast cancer cells lines (MCF7 and MDA-MB-231), whereas Xu et al. [22] reported the proapoptotic property of $\alpha$-mangostin at $16 \mu \mathrm{M}$ in pancreatic cancer cells (BxPC-3 and Panc-1), and Nakagawa et al. [21] reported that $\alpha$-mangostin induces apoptosis in human colon cancer DLD-1 cells with a concentration of $20 \mu \mathrm{M}$. On the other hand, other reports have shown that NDGA and its derivatives could induce apoptosis. For instance, Meyer et al. [46] found a significant increase in PARP cleavage, in a dose-dependent manner, in multiple myeloma cell lines treated with NDGA for $24 \mathrm{~h}$, indicating that NDGA could increase apoptosis. There have also been reports that NDGA in concentrations ranging from $30 \mu \mathrm{M}$ to $100 \mu \mathrm{M}$ induced apoptosis in aggressive and metastatic breast cancer cells resistant to HER2 antibody therapy and tamoxifen [26,43]. Further experiments will deeply analyze the mechanism and the pathways involved in these anti-tumoral effects of $\alpha$-mangostin and NDGA on medulloblastoma cells.

One of the therapeutic approaches against medulloblastoma is chemotherapy such as cisplatin or exisulind, which increases the survival of patients. However, chemotherapy has limitations, such as dosage and efficacy, resistance to therapy, and toxicity side effects. Therefore, it is essential to develop new strategies that reduce these side effects. For example, one strategy would be to use compounds such as $\alpha$-mangostin or NDGA that, in combination with chemotherapy, induce sensitivity to chemotherapy treatment. Indeed, it has been shown that $\alpha$-mangostin or NDGA synergizes the effects of cisplatin or exisulind in cervical or lung cancer, respectively $[47,48]$. Therefore, these compounds $\alpha$-mangostin $20 \mu \mathrm{M}$ or NDGA $75 \mu \mathrm{M}$ could decrease the proliferation of medulloblastoma cells treated with cisplatin or exisulind by increasing the death of cancer cells (compared to cisplatin or exisulind alone). Furthermore, these compounds can be an effective chemosensitizer that selectively damages cancer cells, having less effect on normal cells or healthy tissues.

Taking into account all our data, together with previous reports in the scientific literature that show the ability of both polyphenols to have an effect through the bloodbrain barrier, this suggests the potential use of $\alpha$-mangostin and NDGA as alternative treatments to the conventional therapies against medulloblastoma.

In conclusion, we found evidence that exposure to childhood medulloblastomaderived cell line Daoy with $\alpha$-mangostin or NDGA leads to the inhibition of cell growth, characterized by G2/M arrest, in the case of the first compound and a transient arrest in the $S$ phase followed by G2/M arrest for the second one. Both polyphenols induced cell cycle arrest and a clear induction of apoptosis in the Daoy cells. Importantly, $\alpha$-mangostin exerts more potent suppressive effects in tumoral cell growth and more apoptosis induction than NDGA.

\section{Materials and Methods}

\subsection{Cell Line and Cell Culture}

The Daoy cell line, derived from a primary medulloblastoma tumor, was obtained from the American Type Culture Collection (ATCC number: HTB- $186^{\mathrm{TM}}$, Manassas, VA, USA) and maintained in Eagle's minimum essential medium (EMEM) supplemented with $10 \%$ fetal bovine serum (FBS), penicillin-streptomycin solution (100 U.I.-100 $\mu \mathrm{g} / \mathrm{mL}$ ), and L-glutamine ( $2 \mathrm{mM}$ ) (ATCC, Manassas, VA, USA) at $37^{\circ} \mathrm{C}$ in a $5 \% \mathrm{CO}_{2}$ air humidified atmosphere. NDGA was purchased from Sigma-Aldrich (Toluca, Mexico; catalog number: 
74540), whereas $\alpha$-mangostin was obtained as previously described [49]. The purity of $\alpha-$ mangostin was $98 \%$, as determined by liquid chromatography-electrospray ionization mass spectrometry (LS-ESI-MS), and the melting point of the compound was 179 to $180{ }^{\circ} \mathrm{C}$, as reported in the literature [50]. NDGA and $\alpha$-mangostin were dissolved in dimethylsulphoxide (DMSO) (ATCC, Manassas, VA, USA) at the final stock concentrations of $100 \mathrm{mM}$ and $20 \mathrm{mM}$, respectively, and kept at $-70{ }^{\circ} \mathrm{C}$ and protected from light until used.

\subsection{Cellular Treatments}

For the viability assays, Daoy cells at a density of $1 \times 10^{5}$ cells $/ \mathrm{mL}$ were seeded in a 6-well plate in $2 \mathrm{~mL}$ of culture medium and grown for $24 \mathrm{~h}$. Later, taking as a reference the concentrations of these compounds reported in the literature, the cell cultures were incubated with increasing concentrations of $\alpha$-mangostin $(10,15,20$, and $40 \mu \mathrm{M})$ or NDGA $(25,50,75,100$, and $200 \mu \mathrm{M})$ for $24 \mathrm{~h}$. The concentration range selected for each compound was based on previous reports in the literature. The control cultures were incubated with $0.02 \%$ DMSO $(v / v)$ for $24 \mathrm{~h}$. In the Cell Cycle and Cell Death analysis case, $1 \times 10^{6}$ cells $/ \mathrm{mL}$ were grown in $100-\mathrm{mm}^{3}$ culture dishes in a final volume of $10 \mathrm{~mL}$ and treated with the indicated concentrations of $\alpha$-mangostin or NDGA.

\subsection{Cell Viability Assays}

We used crystal violet and trypan blue dyes to determine the effects of $\alpha$-mangostin and NDGA on the cell viability. In the first case, the culture medium was discharged after cellular incubation with $\alpha$-mangostin or NDGA, and the attached cells were washed twice with $1 \mathrm{~mL}$ of Dulbecco's phosphate-buffered saline (D-PBS) and were fixed with $1 \mathrm{~mL}$ of $1 \%$ formaldehyde overnight. Later, the formaldehyde solution was eliminated, and the cells were stained with $1 \mathrm{~mL}$ of $0.1 \%$ crystal violet for $15 \mathrm{~min}$ at room temperature. The plates were rinsed with water to remove the excess dye and air-dried. Next, the dye incorporated into the cells was eluted with $1 \mathrm{~mL}$ of $10 \%$ acetic acid for $5 \mathrm{~min}$, and a $100-\mu \mathrm{L}$ aliquoted eluted dye was read on a 96-well plate reader at $570 \mathrm{~nm}$ (Multiskan MCC type 355, Fisher Scientific, Vantaa, Finland).

For trypan blue exclusion assays, floating cells were collected from centrifugation and adherent cells were detached with a solution containing $0.25 \%$ trypsin- $-0.53-\mathrm{mM}$ ethylenediaminetetraacetic acid (EDTA) after the indicated treatment with $\alpha$-mangostin or NDGA. Floating and trypsinized cells were joined and immediately centrifugated at 1500 rpm by 5 min (GPR centrifuge, Beckman Instruments Inc., Palo Alto, CA, USA), washed twice, and resuspended in 1-mL D-PBS. Afterward, $10 \mu \mathrm{L}$ of cellular suspension was mixed with $10 \mu \mathrm{L}$ of $0.4 \%$ trypan blue dye and counted immediately in a TC20 ${ }^{\mathrm{TM}}$ automated cell counter (Bio-Rad Laboratories, Inc., Hercules, CA, USA).

\subsection{Carbonyl Proteins and GSH and GSSG Quantifications}

Daoy cells $\left(1 \times 10^{5}\right.$ cells $\left./ \mathrm{mL}\right)$ were seeded in a 6 -well plate in $2 \mathrm{~mL}$ of culture medium and grown for $24 \mathrm{~h}$. Later, the cells were treated with $20-\mu \mathrm{M} \alpha$-mangostin and $75-\mu \mathrm{M}$ NDGA for $24 \mathrm{~h}$, and both floating and adherent cells were harvested; the cell pellet was kept at $-70{ }^{\circ} \mathrm{C}$ until it was used. The carbonyl proteins were measured, as previously described by Levine et al. [51]. This method is based on the reaction of oxidized carbonyl protein groups with 2,4-dinitrophenylhydrazine (2,4-DNPH) to produce dinitrophenyl (DNP) hydrazone, which absorbance is measured at $\lambda=370 \mathrm{~nm}$ on an Epoch model multiple plate reader (BioTek Instruments, Winooski, VT, USA). Briefly, the cell extracts of the treatments were incubated for $1 \mathrm{~h}$ with 10-mM 2,4-DNPH. Then, the proteins were precipitated with $20 \%$ trichloroacetic acid. The proteins were washed four times with an ethanol-ethyl acetate mixture $(1: 1 v / v)$, solubilized in 6-M guanidine hydrochloride, and the absorbance was measured at $\lambda=370 \mathrm{~nm}$.

The total glutathione (glutathione (GSH) + glutathione disulfide (GSSG)) and GSSG were measured by the method described by Rahman et al. [52]. Briefly, GSH is oxidized by 5,5'-dithiobis-2-nitrobenzoic acid (DTNB) to 5-thio-2-nitrobenzoic acid (TNB; detectable at 
$\lambda=412 \mathrm{~nm}$ ) and TNB glutathione adducts (GS-TNB). Glutathione reductase (GR) reduces GS-TNB and GSSG to GSH, which DTNB oxidizes to TNB. Therefore, the amount of total glutathione calculated signifies the sum of GSH and GSSG. Then, GSSG was also evaluated by the Rahman method mentioned above, where the samples were previously treated with 2-vinylpyridine (2-VP). 2-VP covalently associates with GSH, removing it altogether, leaving GSSG as the only measurable substrate of the assay. Finally, GSH was calculated by subtracting GSSG from the total glutathione (GSH + GSSG). The cell extract of each treatment was diluted with $200 \mu \mathrm{L}$ of potassium phosphate EDTA (KPE) buffer (0.1-M potassium phosphate and 5-mM disodium EDTA, pH 7.5). Subsequently, two separate samples of $20 \mu \mathrm{L}$ each and treated with 2-VP were used to measure the total glutathione or GSSG, mixed with DTNB $(2.5 \mathrm{mM})$ and GR $(250 \mathrm{U} / \mathrm{mL})$. Finally, $\beta$-Nicotinamide adenine dinucleotide phosphate reduced ( $\beta$-NADPH) was added, and the absorbance at $\lambda=412 \mathrm{~nm}$ was measured at intervals of $60 \mathrm{~s}$ for $2 \mathrm{~min}$. The rate of change in absorbance for each experiment was compared with the GSH or GSSG standards.

\subsection{Cell Cycle Analysis}

To study the influence of $\alpha$-mangostin and NDGA in cell cycle progression, floating and trypsinized cells were harvested after their respective treatment, pelleted by centrifugation, and washed twice with D-PBS. Cellular pellets were resuspended in $1 \mathrm{~mL}$ of ice-cold $70 \%$ ethanol and maintained at $-20{ }^{\circ} \mathrm{C}$ overnight. Later, cells were washed twice with D-PBS and incubated with $100 \mu \mathrm{L}$ of trypsin solution $(0.03 \mathrm{mg} / \mathrm{mL})$ for $10 \mathrm{~min}$. Next, the cellular suspension was further incubated with $100 \mu \mathrm{L}$ of a solution containing $0.5-\mathrm{mg} / \mathrm{mL}$ trypsin inhibitor- $-0.1-\mathrm{mg} / \mathrm{mL}$ ribonuclease A for $10 \mathrm{~min}$. Then, the DNA was stained with $80 \mu \mathrm{L}$ of propidium iodide $(0.4 \mathrm{mg} / \mathrm{mL})$ for $30 \mathrm{~min}$. Finally, the cell cycle profile was determined in flow cytometer BD FACSCanto ${ }^{\mathrm{TM}} \mathrm{II}$ (BD Biosciences, San Jose, CA, USA). Data were analyzed with FlowJo Office software version X (FlowJo, LLC., Ashland, OR, USA). At least 10,000 events were read for each sample.

\subsection{Cell Death Assay}

To evaluate cell death, we used the LIVE/DEAD assay following the indications of the supplier (LIVE/DEAD Fixable Dead Cell Stain Kits, Invitrogen. Eugene, OR, USA). Briefly, after treating the cell cultures as indicated before, floating and adherent cells were harvested and resuspended in 1-mL D-PBS. Then, $1 \mu \mathrm{L}$ of fluorescent reactive dye was added to the cellular suspension and incubated for $30 \mathrm{~min}$ at room temperature. The cells were washed twice with $1 \mathrm{~mL}$ of D-PBS with $1 \%$ bovine serum albumin and processed in flow cytometer BD FACSAria ${ }^{\mathrm{TM}}$ using $488-\mathrm{nm}$ excitation and emission detected with a 610/20 filter (BD Biosciences, San Jose, CA, USA). At least 10,000 events were captured for each sample. An analysis of the results was performed with FlowJo Office software version $X$ and WinList 3D software version 9.0. (Verity Software House, Topsham, ME, USA)

\subsection{TUNEL Assay}

Daoy cells were treated as indicated before to study the proapoptotic potential of $\alpha$ mangostin and NDGA, and both floating and adherent cells were harvested. The terminal deoxynucleotidyl transferase (TdT) dUTP Nick-End Labeling (TUNEL) assay was performed following the manufacturer's instructions (APO-BrdU TUNEL assay kit, Molecular Probes, Invitrogen, Eugene, OR, USA). Briefly, cells were resuspended in $5 \mathrm{~mL}$ of cold $1 \%$ paraformaldehyde in D-PBS and incubated on ice for $15 \mathrm{~min}$. Later, cells were pelleted by centrifugation and washed twice with D-PBS. Cellular pellets were resuspended in $5 \mathrm{~mL}$ of ice-cold 70\% ethanol and incubated on ice for at least $30 \mathrm{~min}$. Then, the DNA was labeled with bromodeoxyuridine (BrdU) for $60 \mathrm{~min}$ and later stained with Alexa Fluor 488-labeled anti-BrdU antibody for $30 \mathrm{~min}$ at room temperature. Samples were protected from light during the incubations. The results were analyzed in flow cytometer BD FACSAria ${ }^{\mathrm{TM}}$. A minimum of 10,000 events was acquired for each experiment. 


\subsection{Statistical Analysis}

All data represented at least three independent experiments and were expressed as the mean \pm S.E. and were analyzed using statistical program GraphPad Prism 5 (GraphPad Software Inc., La Jolla, CA, USA). $p$-value $<0.05$ was established as significant. Cell viability, cytotoxic effects, and induced apoptosis data were analyzed by one-way analysis of variance and Dunnett's multiple comparison test. ${ }^{*} p<0.0001$ vs. control. Cell cycle arrest data were analyzed by two-way ANOVA and Bonferroni posttests. ${ }^{*} p<0.05$ and ** $p<0.001$. Carbonyl proteins and the GSH and GSSG data were analyzed by ANOVA and Tukey's test: ${ }^{*} p<0.05,{ }^{* *} p<0.005$, and ${ }^{* * *} p<0.0005$.

Author Contributions: Conceptualization, A.R.-O.; methodology, A.R.-O., A.C.-G. (Adela CarrilloGarcía), N.P., A.C.-G. (Alfredo Cruz-Gregorio) and N.O.; formal analysis, A.R.-O., E.J.C. and J.P.-C.; resources, A.R.-O., E.J.C., M.L. and J.P.-C.; writing-original draft preparation, A.R.-O. and A.C.-G. (Adela Carrillo-García); writing—review and editing, A.R.-O., A.C.-G. (Adela Carrillo-García), E.J.C., J.P.-C., M.L. and A.C.-G. (Alfredo Cruz-Gregorio); supervision, A.R.-O.; and funding acquisition, A.R.-O. All authors have read and agreed to the published version of the manuscript.

Funding: This research was partially funded by the Instituto Nacional de Pediatría, México (grant number: 053/2011).

Institutional Review Board Statement: Not applicable. This study not involving humans or animals. Informed Consent Statement: Not applicable for studies not involving humans.

Data Availability Statement: Data openly available in a public repository that issues datasets with https:/ / pubmed.ncbi.nlm.nih.gov/, accessed on 24 November 2021.

Acknowledgments: We acknowledge Rocío Morales Bárcenas for her technical assistance in the flow cytometry measurements. We gratefully acknowledge to the postdoctoral grant programme from the Consejo Nacional de Ciencia y Tecnología (CONACyT) for the postdoctoral fellow position of Alfredo Cruz-Gregorio.

Conflicts of Interest: The authors declare no conflict of interest.

Sample Availability: Samples of the compounds $\alpha$-mangostin and NDGA are available from the authors.

\section{References}

1. Packer, R.J.; Cogen, P.; Vezina, G.; Rorke, L.B. Medulloblastoma: Clinical and biologic aspects. Neuro Oncol. 1999, 1, $232-250$. [CrossRef]

2. Packer, R.J.; MacDonald, T.; Vezina, G. Central nervous system tumors. Pediatr. Clin. N. Am. 2008, 55, 121-145. [CrossRef]

3. Roussel, M.F.; Robinson, G. Medulloblastoma. advances and challenges. F1000 Biol. Rep. 2011, 3, 5. [CrossRef] [PubMed]

4. Dillinger, T.L.; Barriga, P.; Escarcega, S.; Jimenez, M.; Salazar, L.D.; Grivetti, L.E. Food of the gods: Cure for humanity? A cultural history of the medicinal and ritual use of chocolate. J. Nutr. 2000, 130 (Suppl. 8S), 2057S-2072S. [CrossRef] [PubMed]

5. Ramiro-Puig, E.; Castell, M. Cocoa: Antioxidant and immunomodulator. Br. J. Nutr. 2009, 101, 931-940. [CrossRef] [PubMed]

6. Manach, C.; Scalbert, A.; Morand, C.; Remesy, C.; Jimenez, L. Polyphenols: Food sources and bioavailability. Am. J. Clin. Nutr. 2004, 79, 727-747. [CrossRef]

7. D'Archivio, M.; Santangelo, C.; Scazzocchio, B.; Vari, R.; Filesi, C.; Masella, R.; Giovannini, C. Modulatory effects of polyphenols on apoptosis induction: Relevance for cáncer prevention. Int. J. Mol. Sci. 2008, 9, 213-228. [CrossRef]

8. Labbé, D.; Provencal, M.; Lamy, S.; Boivin, D.; Gingras, D.; Béliveau, R. The flavonols quercetin, kaempferol, and myricetin inhibit hepatocyte growth factor-induced medulloblastoma cell migration. J. Nutr. 2009, 139, 646-652. [CrossRef] [PubMed]

9. Arteaga, S.; Andrade, C.A.; Cárdenas, R. Larrea tridentata (Creosote bush), an abundant plant of Mexican and US-American deserts and its metabolite nordihydroguaiaretic acid. J. Etnhopharmacol. 2005, 98, 231-239. [CrossRef]

10. Chan, J.K.W.; Bittner, S.; Bittner, A.; Atwal, S.; Shen, W.J.; Inayathullah, M.; Rajada, J.; Nicolls, M.R.; Kraemer, F.B.; Azhar, S. Nordihydroguaiaretic acid, a lignan from Larrea tridentata (Creosote Bush), protects against american lifestyle-induced obesity syndrome dietinduced metabolic dysfunction in mice. J. Pharmacol. Exp. Ther. 2018, 365, 281-290. [CrossRef]

11. Huang, H.J.; Chen, W.L.; Hsieh, R.H.; Hsieh-Li, H.M. Multifunctional effects of mangosteen pericarp on cognition in C57BL/6J and triple transgenic Alzheimer's mice. Evidence-based complement. Altern. Med. 2014, 2014, 813672. [CrossRef]

12. Pedraza-Chaverri, J.; Cárdenas-Rodríguez, N.; Orozco-Ibarra, M.; Pérez-Rojas, J.M. Medicinal properties of mangosteen (Garcinia mangostana). Food Chem. Toxicol. 2008, 46, 3227-3239. [CrossRef] [PubMed] 
13. Akao, Y.; Nakagawa, Y.; Iinuma, M.; Nozawa, Y. Anti-cancer effects of xanthones from pericarps of mangosteen. Int. J. Mol. Sci. 2008, 9, 355-370. [CrossRef]

14. Shan, T.; Ma, Q.; Guo, K.; Liu, J.; Li, W.; Wang, F.; Wu, E. Xanthones from mangosteen extracts as natural chemopreventive agents: Potential anticancer drugs. Curr. Mol. Med. 2011, 11, 666-677. [CrossRef] [PubMed]

15. Gutierrez-Orozco, F.; Failla, M.L. Biological activities and bioavailability of mangosteen xanthones: A critical review of the current evidence. Nutrients 2013, 5, 3163-3183. [CrossRef]

16. Ovalle-Magallanes, B.; Eugenio-Pérez, D.; Pedraza-Chaverri, J. Medicinal properties of mangosteen (Garcinia mangostana L.): A comprehensive update. Food Chem. Toxicol. 2017, 109, 102-122. [CrossRef]

17. Li, G.; Petiwala, S.M.; Nonn, L.; Johnson, J.J. Inhibition of CHOP accentuates the apoptotic effect of $\alpha$-mangostin from the mangosteen fruit (Garcinia mangostana) in 22Rv1 prostate cancer cells. Biochem. Biophys. Res. Commun. 2014, 453, 75-80. [CrossRef]

18. Won, Y.S.; Lee, J.H.; Kwon, S.J.; Kim, J.Y.; Park, K.H.; Lee, M.K.; Seo, K.-I. $\alpha$-Mangostin-induced apoptosis is mediated by estrogen receptor $\alpha$ in human breast cancer cells. Food Chem. Toxicol. 2014, 66, 158-165. [CrossRef]

19. Matsumoto, K.; Akao, Y.; Kobayashi, E.; Ohguchi, K.; Ito, T.; Tanaka, T.; Iinuma, M.; Nozawa, Y. Induction of apoptosis by xanthones from mangosteen in human leukemia cell lines. J. Nat. Prod. 2003, 66, 1124-1127. [CrossRef]

20. Matsumoto, K.; Akao, Y.; Yi, H.; Ohguchi, K.; Ito, T.; Tanaka, T.; Kobayashi, E.; Iinuma, M.; Nozawa, Y. Preferential target is mitochondria in $\alpha$-mangostin-induced apoptosis in human leukemia HL60 cells. Bioorg. Med. Chem. 2004, 12, 5799-5806. [CrossRef]

21. Nakagawa, Y.; Iinuma, M.; Naoe, T.; Nozawa, Y.; Akao, Y. Characterized mechanism of $\alpha$-mangostin-induced cell death: Caspaseindependent apoptosis with release of endonuclease-G from mitochondria and increased miR-143 expression in human colorectal cancer DLD-1 cells. Bioorg. Med. Chem. 2007, 15, 5620-5628. [CrossRef]

22. Xu, Q.; Ma, J.; Lei, J.; Duan, W.; Sheng, L.; Chen, X.; Hu, A.; Wang, Z.; Wu, Z.; Wu, E.; et al. $\alpha$-Mangostin suppresses the viability and epithelial-mesenchymal transition of pancreatic cancer cells by downregulating the PI3K/Akt pathway. BioMed Res. Int. 2014, 2014, 546353. [CrossRef]

23. Beninati, S.; Oliverio, S.; Cordella, M.; Rossi, S.; Senatore, C.; Liguori, I.; Lentini, A.; Piredda, L.; Tabolacci, C. Inhibition of cell proliferation, migration and invasion of B16-F10 melanoma cells by $\alpha$-mangostin. Biochem. Biophys. Res. Commun. 2014, 450, 1512-1517. [CrossRef] [PubMed]

24. Ibrahim, M.Y.; Hashim, N.M.; Mohan, S.; Abdulla, M.A.; Abdelwahab, S.I.; Arbab, S.A.; Yahayu, M.; Ali, L.Z.; ElhagIshag, O. $\alpha$-Mangostin from Cratoxylum Arborescens: An in Vitro and in Vivo Toxicological Evaluation. Arab. J. Chem. 2015, 8, 129-137. [CrossRef]

25. Yang, S.; Zhou, F.; Dong, Y.; Ren, F. $\alpha$-Mangostin Induces Apoptosis in Human Osteosarcoma Cells Through ROS-Mediated Endoplasmic Reticulum Stress via the WNT Pathway. Cell Transplant. 2021, 30, 9636897211035080. [CrossRef] [PubMed]

26. Rowe, D.L.; Ozbay, T.; Bender, L.M.; Nahta, R. Nordihydroguaiaretic acid, a cytotoxic insulin-like growth factor-I receptor/HER2 inhibitor in trastuzumab-resistant breast cancer. Mol. Cancer Ther. 2008, 7, 1900-1908. [CrossRef]

27. Gao, P.; Zhai, F.; Guan, L.; Zheng, J. Nordihydroguaiaretic acid inhibits growth of cervical cancer SiHa cells by up-regulating p21. Oncol. Lett. 2011, 2, 123-128. [CrossRef]

28. Li, X.; Fan, S.; Pan, X.; Xiaokaiti, Y.; Duan, J.; Shi, Y.; Pan, Y.; Tie, L.; Wang, X.; Li, Y.; et al. Nordihydroguaiaretic acid impairs prostate cancer cell migration and tumor metastasis by suppressing neuropilin 1. Oncotarget 2016, 7, 86225-86238. [CrossRef]

29. Sahu, S.C.; Ruggles, D.I.; O’Donnell, M.W. Prooxidant Activity and Toxicity of Nordihydroguaiaretic Acid in Clone-9 Rat Hepatocyte Cultures. Food Chem. Toxicol. 2006, 44, 1751-1757. [CrossRef] [PubMed]

30. Leon, D.; Parada, D.; Vargas-Uribe, M.; Perez, A.A.; Ojeda, L.; Zambrano, A.; Reyes, A.M.; Salas, M. Effect of Nordihydroguaiaretic Acid on Cell Viability and Glucose Transport in Human Leukemic Cell Lines. FEBS Open Bio 2016, 6, 1000-1007. [CrossRef] [PubMed]

31. Kondo, M.; Zhang, L.; Ji, H.; Kou, Y.; Ou, B. Bioavailability and antioxidant effects of a xanthone-rich mangosteen (Garcinia mangostana) product in humans. J. Agric. Food Chem. 2009, 57, 8788-8792. [CrossRef]

32. Chitchumroonchokchai, C.; Riedl, K.M.; Suksumrarn, S.; Clinton, S.K.; Kinghorn, A.D.; Failla, M.L. Xanthones in mangosteen juice are absorbed and partially conjugated by healthy adults. J. Nutr. 2012, 142, 675-680. [CrossRef]

33. Chang, C.W.; Huang, T.Z.; Chang, W.H.; Tseng, Y.C.; Wu, Y.T.; Hsu, M.C. Acute Garcinia mangostana (mangosteen) supplementation does not alleviate physical fatigue during exercise: A randomized, double-blind, placebocontrolled, crossover trial. J. Int. Soc. Sports Nutr. 2016, 13, 20. [CrossRef] [PubMed]

34. Manda, G.; Rojo, A.I.; Martínez-Klimova, E.; Pedraza-Chaverri, J.; Cuadrado, A. Nordihydroguaiaretic Acid: From Herbal Medicine to Clinical Development for Cancer and Chronic Diseases. Front. Pharmacol. 2020, 11, 151. [CrossRef] [PubMed]

35. Friedlander, T.W.; Weinberg, V.K.; Huang, Y.; Mi, J.T.; Formaker, C.G.; Small, E.J.; Harzstark, A.L.; Lin, A.M.; Fong, L.; Ryan, C.J. A phase II study of insulin-like growth factor receptor inhibition with nordihydroguaiaretic acid in men with non-metastatic hormone-sensitive prostate cancer. Oncol. Rep. 2012, 27, 3-9. [CrossRef]

36. Grossman, S.A.; Ye, X.; Peereboom, D.; Rosenfeld, M.R.; Mikkelsen, T.; Supko, J.G.; Desideri, S. Phase I study of terameprocol in patients with recurrent high-grade glioma. Neuro Oncol. 2012, 14, 511-517. [CrossRef]

37. Li, P.; Tian, W.; Ma, X. Alpha-mangostin inhibits intracellular fatty acid synthase and induces apoptosis in breast cancer cells. Mol. Cancer 2014, 13, 138. [CrossRef] 
38. Kurose, H.; Shibata, M.A.; Linuma, M.; Otsuki, Y. Alterations in cell cycle and induction of apoptotic cell death in breast cancer cells treated with $\alpha$-mangostin extracted from mangosteen pericarp. J. Biomed. Biotechnol. 2012, 2012, 672428. [CrossRef]

39. Mizushina, Y.; Kuriyama, I.; Nakahara, T.; Kawashima, Y.; Yoshida, H. Inhibitory effects of $\alpha$-mangostin on mammalian DNA polymerase, topoisomerase, and human cancer cell proliferation. Food Chem. Toxicol. 2013, 59, 793-800. [CrossRef] [PubMed]

40. Matsumoto, K.; Akao, Y.; Ohguchi, K.; Ito, T.; Tanaka, T.; Linuma, M.; Nozawa, T. Xanthones induce cell-cycle arrest and apoptosis in human colon cancer DLD-1 cells. Bioorg. Med. Chem. 2005, 13, 6064-6069. [CrossRef]

41. Lee, C.H.; Ying, T.H.; Chiou, H.L.; Hsieh, S.C.; Wen, S.H.; Chou, R.H.; Hsieh, Y.H. Alpha-mangostin induces apoptosis through activation of reactive oxygen species and ASK1/p38 signaling pathway in cervical cancer cells. Oncotarget 2017, 8, 47425-47439. [CrossRef]

42. Kwak, H.H.; Kim, I.R.; Kim, H.J.; Park, B.S.; Yu, S.B. $\alpha$-Mangostin induces apoptosis and cell cycle arrest in oral squamous cell carcinoma cell. Evid. Based Complement. Altern. Med. 2016, 2016, 5352412. [CrossRef] [PubMed]

43. Zavodovskaya, M.; Campbell, M.J.; Maddux, B.A.; Shiry, L.; Allan, G.; Hodges, L.; Kushner, P.; Kener, J.A.; Youngren, J.F.; Goldfine, I.D. Nordihydroguaiaretic acid (NDGA), an inhibitor of the HER2 and IGF-1 receptor tyrosine kinases, blocks the growth of HER2-overexpressing human breast cancer cells. J. Cell. Biochem. 2008, 103, 624-635. [CrossRef] [PubMed]

44. Meyer, G.E.; Chesler, L.; Liu, D.; Gable, K.; Maddux, B.A.; Goldenberg, D.D.; Youngren, J.F.; Goldfine, I.D.; Weiss, W.A.; Matthay, K.K.; et al. Nordihydroguaiaretic acid inhibits insulin-like growth factor signaling, growth, and survival in human neuroblastoma cells. J. Cell. Biochem. 2007, 102, 1529-1541. [CrossRef] [PubMed]

45. Zhao, Q.W.; Lin, Y.; Xu, C.R.; Yao, Y.L.; Cui, Y.H.; Zhang, X.; Bian, X.W. NDGA-P21, a novel derivative of nordihydroguaiaretic acid, inhibits glioma cell proliferation and stemness. Lab. Investig. 2017, 97, 1180-1187. [CrossRef]

46. Meyer, A.N.; McAndrew, C.W.; Donoghue, D.J. Nordihydroguaiaretic acid inhibits an activated fibroblast growth factor receptor 3 mutant and blocks downstream signaling in multiple myeloma cells. Cancer Res. 2008, 68, 7362-7370. [CrossRef]

47. Pérez-Rojas, J.M.; González-Macías, R.; González-Cortes, J.; Jurado, R.; Pedraza-Chaverri, J.; García-López, P. Synergic Effect of $\alpha$-Mangostin on the Cytotoxicity of Cisplatin in a Cervical Cancer Model. Oxid. Med. Cell. Longev. 2016, 2016, 7981397. [CrossRef]

48. Soriano, A.F.; Helfrich, B.; Chan, D.C.; Heasley, L.E.; Bunn, P.A.; Chou, T.C. Synergistic Effects of New Chemopreventive Agents and Conventional Cytotoxic Agents against Human Lung Cancer Cell Lines. Cancer Res. 1999, 59, 6178-6184.

49. Nava, C.M.; Acero, G.; Pedraza-Chaverrì, J.; Fragoso, G.; Govezensky, T.; Gevorkian, G. Alpha-mangostin attenuates brain inflammation induced by peripheral lipopolysaccharide administration in C57BL/6J mice. J. Neuroimmunol. 2016, $297,20-27$. [CrossRef]

50. Marquez-Valadez, B.; Maldonado, P.D.; Galvan-Arzate, S.; Mendez-Cuesta, L.A.; Perez de la Cruz, V.; Pedraza-Chaverri, J.; Chánez-Cárdenas, M.E.; Santamaría, A. Alpha mangostin induces changes in glutathione levels associated with glutathione peroxidase activity in rat brain synaptosomes. Nutr. Neurosci. 2012, 15, 13-19. [CrossRef]

51. Levine, R.L.; Williams, J.A.; Stadtman, E.R.; Shacter, E. Carbonyl assays for determination of oxidatively modified proteins. Meth. Enzymol. 1994, 233, 346-357.

52. Rahman, I.; Kode, A.; Biswas, S.K. Assay for quantitative determination of glutathione and glutathione disulfide levels using enzymatic recycling method. Nat. Protoc. 2006, 1, 3159-3165. [CrossRef] [PubMed] 